\title{
Gir fortsatt erstatninger etter svineinfluensavaksinen
}

\author{
Norsk pasientskadeerstatning mottar fortsatt saker fra pasienter som mener \\ de har fått en skade etter svineinfluensavaksinen de fikk for fire år siden.
}

«Det tar kanskje litt tid før man tenker at sykdommen kan ha noe med vaksinen å gjøre»

Rolf Gunnar Jørstad, direktør i Norsk pasientskadeerstatning.
Bare i år har Norsk pasientskadeerstatning mottatt 31 nye saker (1). Det kan være ulike grunner til at folk søker om erstatning så lenge etter, sier direktør i Norsk pasientskadeerstatning, Rolf Gunnar Jørstad.

- Det tar kanskje litt tid før man tenker at sykdommen kan ha noe med vaksinen å gjøre, sier Jørstad.

Av totalt 439 klager som gjelder Pandemrix-vaksinen, har 89 fått medhold. 60 av disse gjelder barn og ungdom som har fått narkolepsi. Ett barn har fått betennelse i ryggmargen. Også 11 voksne har fått erstatning fordi de har fått narkolepsi. Fire personer har fătt nerveskader eller infeksjon etter sprøytestikket, mens én person har fått kronisk utmattelsessyndrom. De øvrige har fått medhold $i$ at de har fătt ulike nevrologiske lidelser og betennelsestilstander etter vaksinen.

Det er utbetalt totalt 89 millioner kroner i erstatninger i disse sakene. 16 år gamle Johanna fortalte til Tidsskriftets podkast i fjor at hun fikk narkolepsi av svineinfluensavaksinen hun tok i 7. klasse (2).

- Siden jeg får katapleksi når jeg ler, så har jeg sluttet å le. Jeg har gjort sånn at jeg ikke synes noe er morsomt lenger, jeg er helt nøytral til det, som en forsvarsmekanisme. På den måten får jeg veldig lite glede, for latter er jo mye av gleden, fortalte 16-åringen (2).

\section{Eline Feiring}

Tidsskriftet

\section{Litteratur}

1. Norsk pasientskadeerstatning. Pandemrix: NPE mottar fortsatt saker. www.npe.no/no/Om-NPE/ Aktuelt/Pandemrix-NPE-mottar-fortsatt-saker/ (2.5.2014).

2. Feiring E. Fikk narkolepsi av svineinfluensavaksinen. http://tidsskriftet.no/Innhold/Nyheter/2013/ Juni/Fikk-narkolepsi-av-svineinfluensavaksinen (2.5.2014).

\section{Ny leder for ny kreftavdeling ved Sykehuset Østfold}

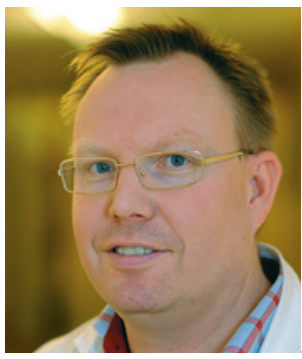

Andreas Stensvold. Foto: Rune Thorstein

Andreas Stensvold (f. 1972) er ansatt som avdelingssjef ved nyetablert kreftavdeling ved Sykehuset $\emptyset$ stfold.

Stensvold kommer fra stillingen som overlege og seksjonsleder ved uroonkologisk seksjon, Oslo universitetssykehus. Han har tidligere vært leder i Norsk onkologisk forening, der han fortsatt sitter i styret. Han er dessuten leder av Norsk Urologisk Cancer Gruppe og sitter i spesialitetskomiteen i onkologi.

Det har vært en utfordring å få tak i kreftleger til Østfold, så all kreftbehandling ble flyttet til sykehuset i Fredrikstad tidligere i vår, mens avdelingen i Moss ble lagt ned. Stensvold begynner i stillingen etter sommeren.

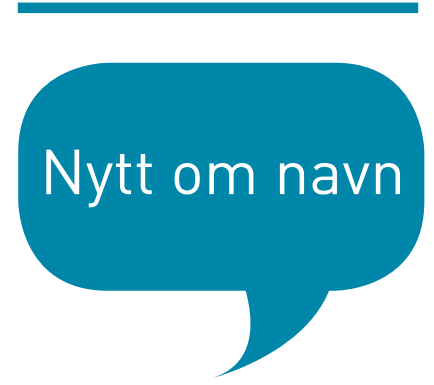

Ove Talsnes er lege i Friidrettsforbundet. Han mener barfotløping, som er blitt så populært, ikke er for alle. - Det er ingen sannhet at du ikke får skader av å løpe barfot, eller av å løpe med sko. (Dagens Næringsliv)

Lars Weisæth er professor emeritus i psykiatri. Han sier at angst er den vanligste reaksjonen hos personer som blir utsatt for negativ medieomtale. - Vi har sett en god del kollapser, innleggelser med mistenkte hjerteinfarkt. Følelsen av å bli forfulgt går igjen. (Dagbladet)

Arnold Berstad er seniorforsker ved Lovisenberg Diakonale Sykehus. Hver eneste uke møter han mennesker som har problemer med irritabel tarm. De fleste av dem har problemer med vanlig sunn mat som brød, melk, frukt og grønnsaker. (TrønderAvisal 


\section{For høy arbeidsbelastning i sykehus?}

De fleste sykehusleger synes arbeidspresset er høyt.

Ved årsskiftet 2013/14 utførte Avdeling for jus og arbeidsliv i Legeforeningen en arbeidstidsundersøkelse blant alle landets sykehusleger (1). Over 6000 leger svarte på henvendelsen, en svarprosent på 52 .

Om lag halvparten av legene hadde faste stillinger, resten hadde tidsbegrensede arbeidsavtaler. Flesteparten av legene uten faste stillinger var leger under spesialisering (LIS-leger). Gjennomsnittlig arbeidstid per uke for legene ifølge tjenesteplanen var 43 timer, men legene hadde i tillegg i gjennomsnitt 2,9 timer uregistrert arbeidstid per uke. På grunnlag av undersøkelsen har Legeforeningen estimert at sykehusleger legger ned ca. 3300 ekstra årsverk utover normal arbeidstid.

Nesten $60 \%$ av legene rapporterer at de opplever den generelle arbeidsbelastningen på sykehusene som belastende eller svært belastende. En tredel synes intensiteten på vakt er passe høy, under $10 \%$ mener at den er lav eller svært lav, mens nesten halvparten av legene mener arbeidsintensiteten er høy eller veldig høy. To tredeler av legene synes det er belastende eller svært belastende å arbeide om natten. I snitt tar legene på seg 10,5 uforutsette vakter (vakansvakter) per år. Flertallet av de spurte mener at det er for få leger ansatt ved deres avdeling, og spesielt etterlyses flere overleger.

- En svakhet ved undersøkelsen er at man ikke har skilt mellom ulike spesialiteter og sykehus, sier Olaf Gjerløw Aasland, instituttsjef ved Legeforskningsinstituttet. - Det gjør at resultatene spriker og at det blir vanskelig å trekke generelle slutninger.

Legeforskningsinstituttets egne undersøkelser tyder på at overleger på sykehus oftere opplever uakseptabelt arbeidspress enn legene i spesialisering (2).

- I en spørreundersøkelse fra 2008 svarte en tredel av overlegene at de nokså ofte eller ofte opplevde dette. Under en femdel av legene i spesialisering svarte det samme. De kvinnelige overlegene opplevde mest arbeidspress. I 2008 svarte nesten $40 \%$ at arbeidspresset ofte var for høyt, mot $30 \%$ i 2000 . Blant leger i spesialisering var det i samme periode ingen økning $\mathrm{i}$ antallet som ofte følte at arbeidspresset var for høyt.

Sammenliknet med andre land er norske leger blant dem som har kortest arbeidstid, påpeker Aasland. - Dette betyr imidlertid ikke at ting ikke kan bli bedre. Tilfredshet $i$ arbeidet avhenger av mange faktorer. Arbeidstid og -belastning er bare to faktorer som spiller en rolle for hvor fornøyde legene er.

\section{Kari Tveito}

Tidsskriftet

\footnotetext{
Litteratur

1. Den norske legeforening. https://legeforeningen.no/nyheter/2014/ undersokelse-om-sykehuslegers-arbeidstid/ (16.5.14)

2. Aasland OG, Rosta J. Hvordan har overlegene det? Overlegen 2011; nr. 1: 47-55.
}

\section{Norsk president i Sveriges läkarförbund}

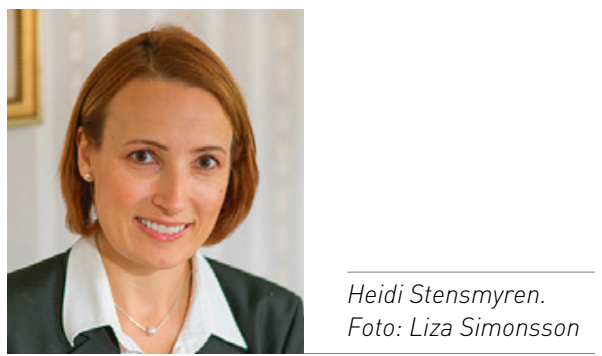

Heidi Stensmyren, norsk anestesilege, ble 16. mai 2014 på årsmøtet i Sveriges läkarförbund valgt til president for de svenske legene.

Stensmyren (f. 1973) tok medisinsk embetseksamen i Würzburg i Tyskland i 1998 og tok spesialistutdanning i anestesi ved Sahlgrenska Universitetssjukhuset 2001-09.

Hun har vært visepresident i den svenske legeforeningen i seks år og var leder for Sveriges Yngre Läkares Förening fra 2007 til 2009.

Hun jobber som anestesilege på Danderyds sykehus, men i Sverige er legepresidentvervet en $80 \%$-stilling, så hun vil nok redusere sykehusstillingen. Hun etterfølger Marie Wedin, som trakk sitt kandidatur.

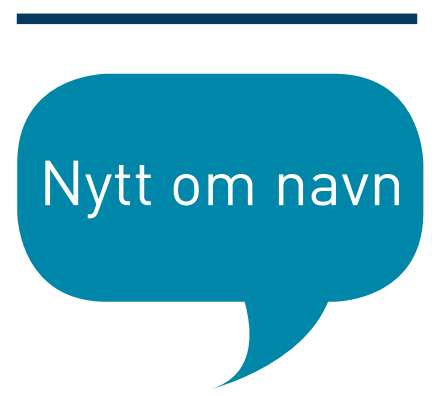

Ole Magnus Filseth er overlege ved Akuttmedisinsk avdeling ved Universitetssykehuset Nord-Norge. Han advarer mot at vårens «hopp-i-havet»-utfordring på Facebook i verste fall kan ta livet av folk. (NRK Nordland)

Shuo-Wang Qiao forsker på cøliaki ved Avdeling for immunologi og transfusjonsmedisin, Universitetssykehuset i Oslo, Rikshospitalet. Hun prøver å forstå hvorfor immunforsvaret lager en slik uønsket betennelsesreaksjon i tarmen og hvorfor den blir trigget av det harmløse glutenproteinet. (Universitetet i Oslo)

Edle Ravndal er professor ved Institutt for klinisk medisin og er tildelt Dr. Oscar Olsens pris for sitt forskningsarbeid om nordmenns alkoholvaner. Hun sier til NRK at nordmenn drikker mer enn før og at vinen er den nye kaffen. (NRK Sørlandet) 